\title{
Probabilistic Identification of Streptoverticillium Species
}

\author{
By S. T. WILLIAMS,${ }^{1}{ }^{*}$ R. LOCCI,${ }^{2}$ J. VICKERS,${ }^{1}$ G. M. SCHOFIELD ${ }^{3}$ \\ P. H. A. SNEATH ${ }^{+}$AND A. M. MORTIMER ${ }^{1}$ \\ ' Department of Botany, University of Liverpool, Liverpool L69 3BX, UK \\ 2 Istituto di Patologia Vegetale, Università degli Studi di Milano, Milano 20133, Italy \\ ${ }^{3}$ Centre for Applied Microbiology and Research, Porton Down, Salisbury SP4 OJG, UK \\ ${ }^{+}$Department of Microbiology, University of Leicester, Leicester LE1 3RH, UK
}

(Received 26 November 1984 ; revised 18 February 1985)

\begin{abstract}
The character state data for clusters defined at the $83 \%$ simple matching coefficient $\left(S_{S M}\right)$ similarity level in a previous phenetic classification were used to construct a probabilistic identification matrix for Streptoverticillium species. The 24 phena included consisted of 10 clusters containing from 2 to 17 strains and 14 single-member clusters. Characters most diagnostic for the clusters were selected from the 185 used in the classification, using previously developed computer programs for determination of character separation indices (CHARSEP) and selection of group diagnostic properties (DIACHAR). The resulting matrix consisted of 41 characters $\times 24$ phena, and identification scores, provided by a program for the identification of unknowns against an identification matrix (MATIDEN), were used for its evaluation. Cluster overlap, calculated by a program for determination of overlap between groups in a matrix (OVERMAT), was generally very small, and the best identification scores possible for most typical examples of each group (MOSTTYP program) were very satisfactory. Input of test data for randomly selected cluster representatives resulted in correct identifications with good scores for the three coefficients provided by the MATIDEN program.
\end{abstract}

\section{INTRODUCTION}

The genus Streptoverticillium was proposed by Baldacci (1958) to accommodate aerobic, sporoactinomycetes forming sporophores arranged in verticils, which had previously been included in the genus Streptomyces. An emendation of Streptoverticillium, involving a more rigorous definition of the configuration of verticils and spore chain umbels, was subsequently made (Baldacci et al., 1966) and a type species designated (Farina \& Locci, 1966).

Streptoverticillia contain LL-diaminopimelic acid and glycine in the wall peptidoglycan (wall chemotype I sensu Lechevalier \& Lechevalier, 1970), major amounts of straight-chain, saturated, iso- and anteiso-fatty acids, mainly hexa- and octahydrogenated menaquinones and diphosphatidylglycerol, phosphatidylethanolamine, phosphatidylinositol and phosphatidylinositol mannosides (Collins et al., 1977; Lechevalier et al., 1977, 1981; Minnikin \& O’Donnell, 1984). The guanine + cytosine of their DNA ranges from 69 to $73 \mathrm{~mol} \%$ (Pridham \& Tresner, 1974). They share these properties with streptomycetes, with which they show high DNA homology values (Kroppenstedt et al., 1981); streptoverticillia and streptomycetes are also lysed by the same polyvalent phages (Prauser, 1976; Wellington \& Williams, 1981). Thus these two genera are obviously closely related. However, the genus Streptoverticillium has been clearly distinguished from Streptomyces in several numerical phenetic studies (Kuryolwicz et al., 1975; Locci et al., 1981; Williams et al., 1983a) and the morphological distinctions between the two genera were emphasized by studies of the fine structure of streptoverticillia spores and sporophores (Locci \& Petrolini 1970; Cross et al., 1973).

The classification and recognition of species of streptoverticillia were initially based largely

Abbreriation: VSP, variance of separation potential. 
on the pigmentation of their spores and mycelia. These criteria were adopted by Locci et al. (1969) and a similar approach in the 8th edition of Bergey's Manual of Determinative Bacteriology (Baldacci \& Locci, 1974) resulted in the allocation of 40 species to 12 series. More recently attempts have been made to classify Streptoverticillium species on the basis of overall similarity (Locci et al., 1981; Williams et al., 1983a). Most of the streptoverticillia included in the numerical phenetic study of Williams et al. $(1983 a)$ were distributed between six clusters. The investigation of Locci et al. (1981) involved the determination of 185 unit characters of 111 strains of Streptoverticillium and Streptomyces which produced pseudoverticillate sporophores. This resulted in the clear separation of streptoverticillia from streptomyces, the former being distributed between 10 multi-membered and 14 single-membered clusters.

Comprehensive classification data can be used for the development of a probabilistic identification matrix containing the minimum number of characters needed to discriminate between the clusters (Hill, 1974). Such a system has many advantages over the widely used monothetic sequential keys which are very susceptible to test error (Sneath, 1974). The classification data of Williams et al. (1983a) were used to develop a probabilistic matrix for the major clusters of Streptomyces (Williams et al., 1983b), its construction and evaluation being based on computer programs devised for this purpose (Sneath, 1979a, $b, 1980 a, b, c$ ). Therefore, it was decided to apply the same procedures to the classification data of Locci et al. (1981) to produce a probabilistic identification scheme for Streptoverticillium species.

\section{METHODS}

Strains and clusters. General details of the Streptoverticillium strains classified and their clustering at the $84 \%$ $S_{S M}$ similarity level were given by Locci et al. (1981). The clusters are named, where possible, after the earliest validly described species which they contained.

Selection of characters most diagnostic of the clusters. The minimum number of characters required to differentiate between the 24 clusters were selected from the 185 unit characters used to construct the classification matrix (Locci et al., 1981).

The diagnostic value of all characters was determined and ranked using the CHARSEP program (Sneath, $1979 \mathrm{~b}$ ), which provides character separation indices for an identification matrix. The 50 most diagnostic tests were selected and then progressively reduced to the minimum required to give good identification scores for the hypothetical median organism of each cluster, as determined by the MOSTTYP program (Sneath, 1980b), which provides the best scores possible for a typical member of each group in a matrix. Finally, the character selection was checked by the DIACHAR program (Sneath, 1980a) which determines the most diagnostic properties of each group in a matrix, ranking the diagnostic scores of each character.

Determination of characters selected for the identification matrix. To help workers who may wish to use the identification system, details of the methods used to determine the 41 characters included in the final matrix are given. The character numbers quoted are those used in the identification matrix (Table 1). In all cases, the inoculum consisted of dense spore and/or mycelial suspensions in sterile water; negative results were re-tested to reduce the possibility of false readings due to poor viability of the inoculum. Incubation was at $27^{\circ} \mathrm{C}$ unless stated. All media were adjusted to $\mathrm{pH} 7 \cdot 0$.

(i) Colony appearance and pigmentation (character numbers 1-4). These were determined from 14-d-old cultures on inorganic salts/starch medium (ISP medium 4; Difco; Shirling \& Gottlieb, 1966). The appearance of the aerial growth was designated as 'cottony' or 'powdery' and spore mass colour was determined against the colour wheels of Tresner \& Backus (1963). Production of melanin pigment was determined after $4 \mathrm{~d}$ on peptone iron agar (ISP medium 6; Difco; Shirling \& Gottlieb, 1966).

(ii) Utilization of carbon and nitrogen sources (character numbers 5-13). Tests were done in Repli dishes (Sterilin). Carbon and nitrogen sources were filter-sterilized and added to the basal media. Sugars (characters 5-8) were incorporated into carbon utilization medium (ISP medium 9; Difco; Shirling \& Gottlieb, 1966) at a concentration of $1 \%(w / v)$. Other sources (characters 9-12) were added to the basal medium of Goodfellow (1971), consisting of Bacto-Yeast Nitrogen Base (Difco) supplemented with $10 \mathrm{mg}$ Casamino acids $1^{-1}$ (Difco), to give concentrations of $0.1 \%(\mathrm{w} / \mathrm{v})$. DL- $\alpha$-Aminobutyric acid (character 13) was incorporated into a basal medium containing $\left(1^{-1}\right): 10 \mathrm{~g}$ glucose, $1 \mathrm{~g} \mathrm{~K}_{2} \mathrm{HPO}_{4}, 0.5 \mathrm{~g} \mathrm{MgSO}_{4} .7 \mathrm{H}_{2} \mathrm{O}, 0.5 \mathrm{~g} \mathrm{NaCl}$, and $15 \mathrm{~g}$ agar to give a concentration of $1 \%(w / v)$ (Williams et al., 1983a).

Cultures were incubated for $14 \mathrm{~d}$, the ability of a strain to utilize a source being determined by comparison of its growth with that on the unsupplemented basal media.

(iii) Acid production from sugars (character numbers 14-18). The basal medium contained $\left(1^{-1}\right) ; 1 \mathrm{~g}\left(\mathrm{NH}_{4}\right)_{2} \mathrm{HPO}_{4}$, $0.02 \mathrm{~g} \mathrm{KCl}, 0.2 \mathrm{~g} \mathrm{MgSO}_{4} .7 \mathrm{H}_{2} \mathrm{O}, 15 \mathrm{~g}$ agar and $15 \mathrm{ml}$ of a $0.04 \%(w / v)$ solution of bromcresol purple (Gordon, 1968). Filter-sterilized carbohydrates were added separately to give a concentration of $1 \%(w / v)$. Acid production, as shown by the $\mathrm{pH}$ indicator, was determined after $14 \mathrm{~d}$. 
(iv) Degradation (character numbers 19-26). Aesculin $(0 \cdot 1 \%$, w/v) degradation was determined after Kutzner (1976) with a basal medium containing $\left(\mathrm{l}^{-1}\right): 3 \mathrm{~g}$ yeast extract (Oxoid), $0 \cdot 5 \mathrm{~g}$ ferric ammonium citrate and $7 \cdot 5 \mathrm{~g} \mathrm{Lab}$ $\mathrm{M}$ agar. Cultures were examined after $7 \mathrm{~d}$ for blackening of the medium. The degradation of DNA $(0.2 \%)$ was observed on Bacto-DNase Test agar (Difco), plates being flooded with $1 \mathrm{M}-\mathrm{HCl}$ to reveal clearance zones after $7 \mathrm{~d}$. Hypoxanthine $(0.4 \%, \mathrm{w} / \mathrm{v})$ and L-tyrosine $(0.5 \%, \mathrm{w} / \mathrm{v})$ degradation was detected using modified Bennett's agar (Williams et al., 1983a) which contained ( $\left.\mathrm{l}^{-1}\right): 1 \mathrm{~g}$ yeast extract (Oxoid), $0.8 \mathrm{~g} \mathrm{Lab-Lemco} \mathrm{(Oxoid),} 10 \mathrm{~g}$ glycerol, $2 \mathrm{~g} \mathrm{NZ}$ amine type A (casein digest) and $15 \mathrm{~g}$ agar. Cultures were examined for clearing of the medium after $14 \mathrm{~d}$. Sierra's (1957) medium supplemented with Tween 20 was examined for opacity around colonies after $7 \mathrm{~d}$. Citrate degradation was determined after Gordon (1968) with a medium containing $\left(1^{-1}\right): 2$ g sodium citrate, $1 \mathrm{~g} \mathrm{NaCl}$, $0.2 \mathrm{~g}\left(\mathrm{NH}_{4}\right)_{2} \mathrm{HPO}_{4}, 0.1 \mathrm{~g} \mathrm{KH} \mathrm{PO}_{4}, 15 \mathrm{~g}$ agar and $20 \mathrm{ml}$ of a $0.04 \%(\mathrm{w} / \mathrm{v})$ solution of phenol red. A positive reaction was established by the alkaline colour of the indicator after $7 \mathrm{~d}$.

Nitrate reduction was determined in a broth consisting of $\left(1^{-1}\right): 5 \mathrm{~g}$ peptone (Oxoid), $3 \mathrm{~g}$ beef extract (Oxoid) and $1 \mathrm{~g} \mathrm{KNO}_{3}$. After $7 \mathrm{~d}$ nitrate was detected by addition of $0.2 \mathrm{ml}$ each of Griess-Ilosvay reagents I and II to the broth. Hydrogen sulphide production was detected by insertion of lead acetate paper strips into the mouths of slope cultures on peptone iron agar (Difco) which were incubated for $14 \mathrm{~d}$ (Küster \& Williams, 1964).

(v) Growth inhibition (character numbers 27-38). Presence or absence of growth at $12^{\circ} \mathrm{C}$ was determined after incubation for $14 \mathrm{~d}$.

Modified Bennett's agar (Williams et al., 1983a) was used as the basal medium to test for growth in the presence of $5 \%(\mathrm{w} / \mathrm{v}) \mathrm{NaCl}, 0.3 \%(\mathrm{w} / \mathrm{v})$ 1-phenylethanol, $0.01 \%(\mathrm{w} / \mathrm{v})$ potassium tellurite, $0.01 \%(\mathrm{w} / \mathrm{v})$ crystal violet and $0.01 \%(w / v)$ malachite green. Plates were examined for growth after $14 \mathrm{~d}$.

Resistance to antibiotics was determined by placing four sensitivity discs (Oxoid) onto a pre-seeded medium which contained $\left(\mathrm{l}^{-1}\right): 30$ g glycerol, $2 \mathrm{~g} \mathrm{~K}_{2} \mathrm{HPO}_{4}, 1 \mathrm{~g} \mathrm{MgSO}_{4} .7 \mathrm{H}_{2} \mathrm{O}, 0 \cdot 5 \mathrm{~g} \mathrm{KCl}, 0 \cdot 01 \mathrm{~g} \mathrm{FeSO}_{4} .7 \mathrm{H}_{2} \mathrm{O}$ and $12 \mathrm{~g}$ agar (Williams, 1967). The discs contained carbenicillin $(100 \mu \mathrm{g})$, azlocillin, cephaloridine, cephalotin, cephamandole and colistin $(30 \mu \mathrm{g})$. The presence of inhibition zones was noted after $4 \mathrm{~d}$.

(vi) Antibiosis (character numbers 39-4I). Plates of nutrient agar (Difco) in glass Petri dishes were spotinoculated with streptoverticillia and incubated for $7 \mathrm{~d}$. They were then inverted and $1.5 \mathrm{ml}$ chloroform was added to the lids and left for $1 \mathrm{~h}$ to kill the colonies. After removal of excess vapour in a laminar flow cabinet, plates were overlaid with $10 \mathrm{ml}$ 'sloppy' agar (nutrient agar; $0.7 \%, \mathrm{w} / \mathrm{v}$ ) seeded with the test organisms: Aspergillus niger (Centraalbureau voor Schimmelcultures, Baarn, the Netherlands; CB5 131.52), Bacillus subtilis (National Collection of Industrial Bacteria, Aberdeen, UK; NCIB 3610) and Candida albicans (Institute of Hygiene, University of Cologne, Cologne, FRG; HIK 183). Overlaid cultures were examined for zones of inhibition after $3 \mathrm{~d}$.

Evaluation of the identification matrix. Cluster overlap was assessed using the OVERMAT program (Sneath, $1980 \mathrm{c}$ ), which determines overlap between groups in a matrix containing percentage positive values for character states. The significance of any overlap is assessed against selected critical values $\left(V_{0}\right)$, which in this case were $1 \%$ and $10 \%$

Identification scores were obtained by the MATIDEN program (Sneath, 1979a), which provides the best scores for a known or unknown strain against the matrix. The identification coefficients determined were the Willcox probability (Willcox et al., 1973), taxonomic distance and standard error of the taxonomic distance. With the former, a score approaching 1.0 indicates a high probability of identification, low scores for taxonomic distance indicate relatedness and acceptable values for the standard error of taxonomic distance are less than about $2 \cdot 0-3 \cdot 0$, negative values indicating that the unknown is closer to the centroid than average. Fuller details of these coefficients can be obtained from Sneath $(1979 a)$ and Williams et al. (1983b). In addition to providing the scores for the best fit to the matrix, MATIDEN also lists scores for the two next best alternatives: properties of the unknown which are atypical of the best fit taxon and characters which distinguish the unknown from the two nearest taxa.

Identification coefficients for the hypothetical median organism of each cluster were determined by the MOSTTYP program (Sneath, 1980 b), which provides the best scores achievable by an entirely typical example of each group in a matrix.

Finally, the matrix was evaluated by determining the identification scores for strains from each cluster. Strains were selected randomly and the results of the appropriate tests obtained in the classification study (Locci et al., 1981) were included.

\section{RESULTS}

Selection of characters most diagnostic of the clusters

The diagnostic scores provided by the CHARSEP program (Sneath, 1979b) and the evaluation of decreasing numbers of the best 50 tests by MOSTTYP (Sneath, 1980 $\mathrm{b}$ ) indicated that a minimum of 41 characters was required. Therefore these were used to construct an identification matrix consisting of 24 clusters $\times 41$ characters (Table 1). 


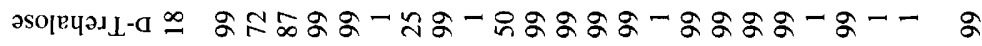

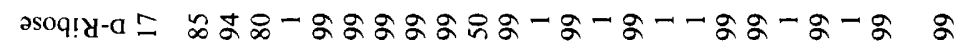

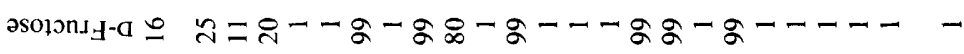

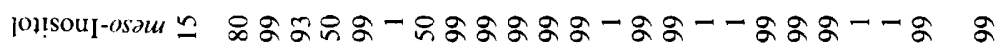

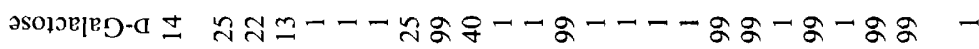

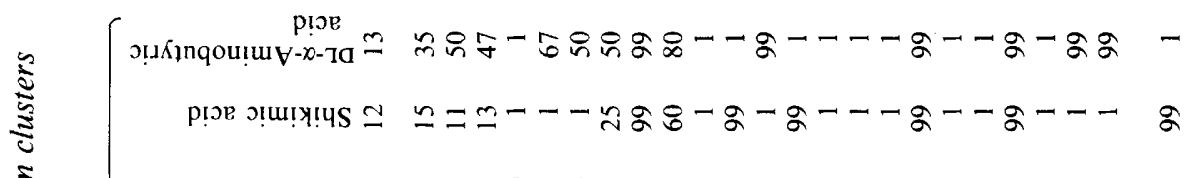

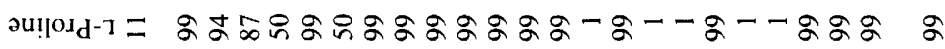

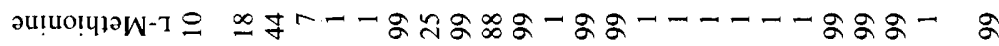

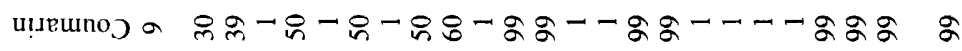

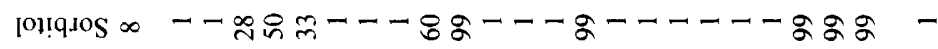
วsoumey

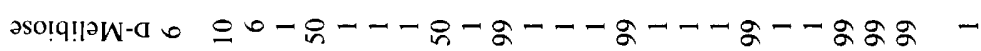

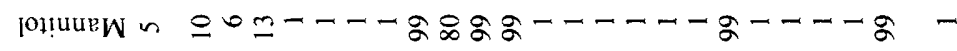
แ!นคว

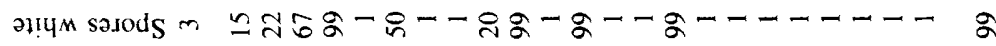
Moll

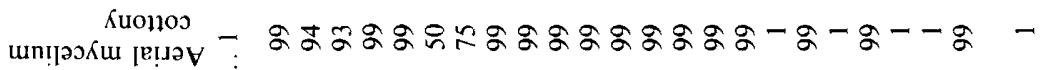
烍

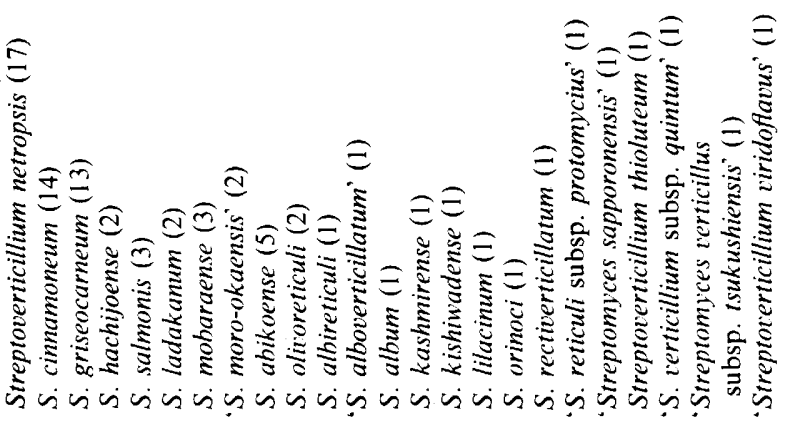

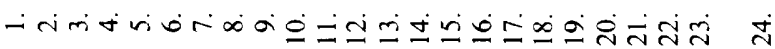




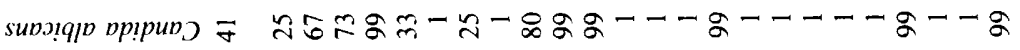

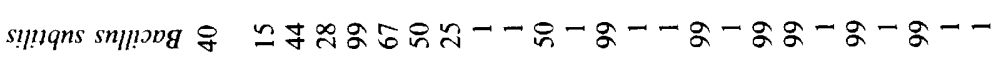

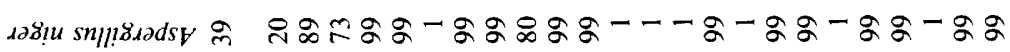
u!̣!!กว $\underset{m}{\infty}$ n。

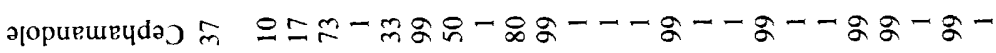
u!̣opчdaว

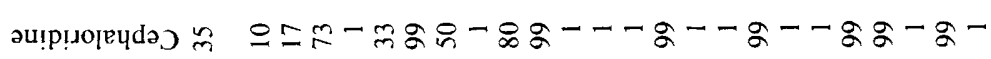

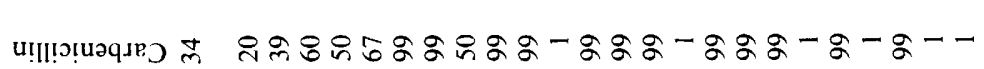

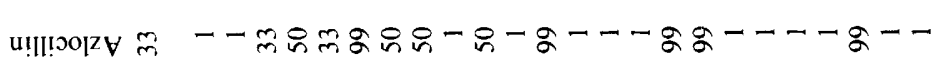

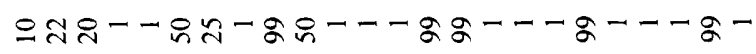

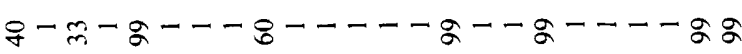
ทNA

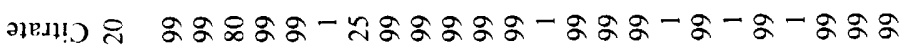
แ!nosav 2 - 
Table 2. Sum of scores of the most diagnostic character-states for each cluster provided by the DIACHAR program

Scores for single-member clusters ranged from 23.87 (' $S$. alboverticillatum') to 26.55 ( $S$. orinoci).

\section{Cluster}

1. Streptoverticillium netropsis

2. S. cinnamoneum

3. S. griseocarneum

4. S. hachijoense

5. S. salmonis

6. S. ladakanum

7. S. mobaraense

8. 'S. moro-okaensis'

9. S. abikoense

10. S. olivoreticuli

$\begin{array}{cc}\begin{array}{c}\text { No. of } \\ \text { strains }\end{array} & \text { Sum of scores } \\ 17 & 13 \cdot 35 \\ 14 & 11 \cdot 54 \\ 13 & 11 \cdot 56 \\ 2 & 18 \cdot 10 \\ 3 & 19 \cdot 01 \\ 2 & 18 \cdot 81 \\ 3 & 14 \cdot 19 \\ 2 & 20 \cdot 04 \\ 5 & 16 \cdot 64 \\ 2 & 20 \cdot 34\end{array}$

Table 3. Identification scores for the hypothetical median organisms of each cluster provided by the MOSTTYP program

\begin{tabular}{|c|c|c|c|}
\hline \multirow[b]{2}{*}{ Cluster } & \multicolumn{3}{|c|}{ Identification score } \\
\hline & $\begin{array}{l}\text { Willcox } \\
\text { probability }\end{array}$ & $\begin{array}{c}\text { Taxonomic } \\
\text { distance }\end{array}$ & $\begin{array}{l}\text { Standard error of } \\
\text { taxonomic distance }\end{array}$ \\
\hline 1. Streptoverticillium netropsis & 0.999 & $0 \cdot 220$ & $-3 \cdot 560$ \\
\hline 2. S. cinnamoneum & 0.996 & $0 \cdot 249$ & $-3 \cdot 200$ \\
\hline 3. S. griseocarneum & 0.999 & $0 \cdot 260$ & -3.189 \\
\hline 4. S. hachijoense & $1 \cdot 000$ & $0 \cdot 247$ & -2.953 \\
\hline 5. S. salmonis & 0.999 & $0 \cdot 171$ & -4.095 \\
\hline 6. S. ladakanum & 1.000 & 0.259 & -2.914 \\
\hline 7. S. mobaraense & 1.000 & $0 \cdot 256$ & -3.099 \\
\hline 8. 'S. moro-okaensis' & $1 \cdot 000$ & $0 \cdot 221$ & -3.059 \\
\hline 9. S. abikoense & 1.000 & $0 \cdot 291$ & -3.609 \\
\hline 10. S. olivoreticuli & 1.000 & 0.221 & $-3 \cdot 059$ \\
\hline
\end{tabular}

The diagnostic value of these characters, as indicated, for example, by the variance of separation potential (VSP; Sneath, 1979b) ranged from $84.23 \%$ (utilization of methionine) and $81 \cdot 16 \%$ (degradation of DNA) to $46 \cdot 56 \%$ (cottony aerial mycelium) and 45.54 (yellow spores). Values overall were higher than those obtained for the streptomycete matrix (Williams et al., $1983 \mathrm{~b}$ ), due to the inclusion of the single-member clusters, but adherence to the strict sequential selection procedure proved to be necessary to obtain a workable matrix.

Final assessment of the test selection using the DIACHAR program (Sneath, 1980a) produced sums of scores ranging from 11.54 to 20.34, with those for single-member clusters inevitably being very high (Table 2). Values for multi-membered clusters were higher than those obtained by Williams et al. (1983b), which ranged from $9 \cdot 36$ to 18.56 . The comparatively low scores for clusters 2 and 3 indicated that they were less sharply defined than the others.

\section{Evaluation of the identification matrix}

Assessment of the overlap between clusters in the matrix, provided by the OVERMAT program (Sneath, $1980 c$ ), indicated that it was insignificant at a critical overlap value $\left(V_{\mathrm{o}}\right)$ of $1 \%$ in most cases. The exceptions were clusters 1 and 5,2 and 4, and 3 and 4, which showed some overlap at a $V_{o}$ value of $10 \%$.

Identification scores for the hypothetical median organism (MOSTTYP; Sneath, 1980b) can be regarded as the best possible attainable for each cluster. Application of MOSTTYP to the final matrix produced good scores for clusters 1 to 10 (Table 3), with Willcox probabilities of 0.999 to 1.000 (except for cluster 2), low taxonomic distances $(0.171-0.260)$ and highly negative standard errors of taxonomic distance. Clearly, this program is irrelevant to single-member clusters, all of which produced identical, ideal scores. 
Table 4. Identification scores for cluster representatives obtained from classification data

(Locci et al., 1981)

\begin{tabular}{|c|c|c|c|c|}
\hline \multirow[b]{2}{*}{$\begin{array}{c}\text { Cluster } \\
\text { no. }\end{array}$} & \multirow[b]{2}{*}{$\begin{array}{l}\text { Cluster } \\
\text { representative* }\end{array}$} & \multicolumn{3}{|c|}{ Identification score } \\
\hline & & $\begin{array}{l}\text { Willcox } \\
\text { probability }\end{array}$ & $\begin{array}{l}\text { Taxonomic } \\
\text { distance }\end{array}$ & $\begin{array}{l}\text { Standard error of } \\
\text { taxonomic distance }\end{array}$ \\
\hline \multirow[t]{3}{*}{1.} & Streptoverticillium baldaccii IPV 1339 & $1 \cdot 00$ & $0 \cdot 331$ & $-0 \cdot 620$ \\
\hline & S. kentuckense IPV 1958 & 0.978 & $0 \cdot 349$ & $-0 \cdot 166$ \\
\hline & S. hiroshimense IPV 2015 & $1 \cdot 000$ & $0 \cdot 261$ & $-2 \cdot 393$ \\
\hline \multirow[t]{3}{*}{2.} & S. cinnamoneum IPV 1776 & 0.996 & 0.285 & $-2 \cdot 177$ \\
\hline & S. paucisporogenes' IPV 2264 & 1.000 & $0 \cdot 270$ & -2.536 \\
\hline & S. sporiferum' IPV 2261 & 1.000 & $0 \cdot 375$ & $-0 \cdot 014$ \\
\hline \multirow[t]{3}{*}{3.} & S. griseocarneum IPV 1959 & $1 \cdot 000$ & $0 \cdot 375$ & $-0 \cdot 342$ \\
\hline & S. mashuense IPV 1986 & $0 \cdot 828$ & $0 \cdot 395$ & $0 \cdot 127$ \\
\hline & S. tropicalensis" IPV 2245 & 0.997 & $0 \cdot 370$ & -0.448 \\
\hline 4. & S. hachijoense IPV 2014 & $1 \cdot 000$ & $0 \cdot 247$ & -0.449 \\
\hline \multirow[t]{2}{*}{5.} & S. aureoversales IPV 2035 & 1.000 & $0 \cdot 233$ & -0.831 \\
\hline & S. salmonis IPV 2019 & $1 \cdot 000$ & $0 \cdot 266$ & $0 \cdot 336$ \\
\hline \multirow[t]{2}{*}{6.} & S. ladakanum var. 'ladakanum' IPV 2163 & $1 \cdot 000$ & $0 \cdot 260$ & $-0 \cdot 393$ \\
\hline & S. verticillius' IPV 2227 & $1 \cdot 000$ & $0 \cdot 260$ & -0.393 \\
\hline \multirow[t]{2}{*}{7.} & S. mobaraense IPV 2058 & 1.000 & $0 \cdot 300$ & $-1 \cdot 020$ \\
\hline & S. thioluteum IPV 2050 & 1.000 & $0 \cdot 320$ & -0.496 \\
\hline 8. & S. aspergilloides' IPV 2244 & 1.000 & $0 \cdot 221$ & -0.597 \\
\hline \multirow[t]{2}{*}{9.} & S. rimofaciens' IPV 2221 & $1 \cdot 000$ & $0 \cdot 303$ & -0.654 \\
\hline & S. abikoense IPV 2225 & 1.000 & $0 \cdot 362$ & 0.965 \\
\hline 10. & S. hachijoense subsp. 'takahagiense' & $1 \cdot 000$ & $0 \cdot 221$ & -0.597 \\
\hline
\end{tabular}

* Names in inverted commas are not on the Approved Lists of Bacterial Names (Skerman et al., 1980). IPV, Istituto di Patologia Vegetale, Università degli Studi di Milano, Milan, Italy.

Identification scores for cluster representatives using data from the classification study are given in Table 4. All strains identified to the parent clusters, the vast majority doing so with clearly acceptable scores for each coefficient. The one notable exception was Streptoverticillium mashuense IPV 1986, a representative of cluster 3, which had a low Willcox probability. As anticipated, all single-member cluster strains identified correctly with highly significant scores.

\section{DISCUSSION}

The results of this study, together with those of Williams et al. (1983b) on streptomycetes, underline the potential value of numerical classification data for the construction of a probabilistic identification system.

As all the streptoverticillia classified by Locci et al. (1981) were included, the identification matrix contained data for most of the type species in the genus. Although some of the computer programs used in the construction and testing of the matrix were irrelevant for the singlemember clusters, we were able to produce a workable matrix which encompassed all the taxa defined by Locci et al. (1981). It should therefore serve as a useful reference system for future identification of unknown strains.

The minimum number (41) of tests required for construction of a reliable matrix was coincidentally the same as that used to differentiate between the 23 major streptomycete clusters (Williams et al., 1983 b). As most of the 24 streptoverticillia clusters were smaller than those of the streptomycetes, this was surprising. It was probably due to the greater degree of overlap which occurred between some of the larger streptoverticillia clusters; the number of tests required is clearly dependent on the variation within clusters. Although the phenetic classification studies on streptomycetes and streptoverticillia had many tests in common, it is interesting to note that the resulting identification matrices shared only eight characters. 
The tests selected for the streptoverticillia matrix covered a wide range of properties, including carbon source utilization, degradation, growth inhibition and antibiosis. However, morphological and pigmentation characteristics, which have been given great emphasis in previous attempts to group Streptoverticillium species (Locci et al., 1969; Baldacci \& Locci, 1974) were not well represented. Only white spores, yellow spores and cottony aerial mycelium were included, and their VSP indices (determined by the CHARSEP program; Sneath, 1979 b) were relatively low at $51 \cdot 14 \%, 45 \cdot 29 \%$ and $46.56 \%$ respectively. The best VSP score for pigmentation of the substrate mycelium (yellow) was $45.29 \%$, just excluding it from the matrix, while other pigments were of little or no diagnostic value. Likewise, soluble pigments were of little value, the best VSP score being $24.58 \%$ for yellow/brown pigmentation. Thus the use of these 'traditional' characters for streptoverticillia results in highly artificial groupings.

In the evaluation of the streptomycete system, unknown isolates were tested and identified against the matrix (Williams et al., 1983b). This was not feasible with streptoverticillia as few are available and they appear to be difficult to isolate from soil and other habitats. Most of the type cultures have originated from workers screening isolates for antibiotics; 30 of the 40 species listed by Baldacci \& Locci (1974) produced named antibiotics and another seven showed antimicrobial activity. Information on the sources and methods used to detect these strains is generally unavailable. Therefore, the ecology of streptoverticillia is still somewhat enigmatic. The results presented here should facilitate identification of any future isolates and might also serve as a basis for the development of more objective isolation procedures, as demonstrated for streptomycetes (Vickers et al., 1984). Provision of a range of unknown isolates would allow evaluation of the matrix using strains not involved in its construction, which is the ultimate test of any identification system (Sneath \& Sokal, 1973). Isolation of more strains should also eventually lead to a more accurate assessment of the overall variation and speciation within the genus. The disproportionate number of single-member clusters defined by Locci et al. (1981) may well be a reflection of the inadequacies of current sampling and isolation procedures.

Despite these problems, this study has provided a theoretically sound, workable identification system for known Streptoverticillium species.

This work was supported by the Science and Engineering Research Council and the British Council.

\section{REFERENCES}

BaldaCCI, E. (1958). Developments in the classification of actinomycetes. Giornale di microbiologia 6, 10 27.

Baldacci, E. \& LocCI, R. (1974). Genus II. Streptoverticillium Baldacci 1958, 15 emend. mut. char. Baldacci, Farina and Locci 1966, 168. In Bergey's Manual of Determinative Bacteriology, 8th edn, pp. $829-842$. Edited by R. E. Buchanan \& N. E. Gibbons. Baltimore: Williams \& Wilkins.

BaldaCCI, E., FARINA, G. \& LoCCI, R. (1966). Emendation of the genus Streptoverticillium Baldacci (1958) and revision of some species. Giornale di microbiologia 14, 153-171.

Collins, M. D., Pirouz, T., Goodfellow, M. \& Minnikin, D. E. (1977). Distribution of menaquinones in actinomycetes and corynebacteria. Journal of General Microbiology 100, 22I-230.

Cross, T., Atrwell, R. W. \& Locci, R. (1973). Fine structure of the spore sheath in Streptoverticillium species. Journal of General Microbiology 75, 421-424.

Farina, G. \& LoccI, R. (1966). Contribution to the study of Streptoverticillium. Description of a new species (Streptoverticillium baldacci sp. nov.) and examination of previously illustrated species. Giornale di microbiologia 14, 33-52.

Goodfellow, M. (1971). Numerical taxonomy of some nocardioform bacteria. Journal of General Microbiology 69, 33-80.

Gordon, R. E. (1968). The taxonomy of soil bacteria. In The Ecology of Soil Bacteria, pp. 293-321. Edited by T. R. G. Gray \& D. Parkinson. Liverpool: Liverpool University Press.

HiLl, L. R. (1974). Theoretical aspects of numerical identification. International Journal of Systematic Bacteriology 24, 494-499.

KropPENSTEDT, R. M., KORN-WENDISCH, F., FoWler, V. J. \& StACKEBRANDT, E. (1981). Biochemical and molecular genetic evidence for a transfer of Actinoplanes armeniacus into the family Streptomyceteae. Zentralblatt für Bakteriologie, Parasitenkunde, Infektionskrankheiten und Hygiene (Abteilung I, Originale C) 2, 254-262.

Kuryzowicz, W., Pasziewicz, A., Woźnicka, W., Kurzatowski, W. \& Szulga, T. (1975). Classification of Streptomyces by different numerical methods. Postepy higieny i medycyny doswiadczalnej 29, 281 355.

Küster, E. \& Williams, S. T. (1964). Production of hydrogen sulphide by streptomycetes and methods for its detection. Applied Microbiology 12, 46-52. 
K UTZNER, H. J. (1976). Methoden zur Untersuchung von Streptomycen und einigen anderen Actinomyceten. Darmstadt: Teilsammlung Darmstadt am Institut für Mikrobiologie der Technischen Hochschule.

LechevalieR, M. P. \& Lechevalier, H. A. (1970). Chemical composition as a criterion in the classification of aerobic actinomycetes. International Journal of Systematic Bacteriology 20, 435-443.

LecheValier, M. P., De Biévre, C. \& Lechevalier, H. A. (1977). Chemotaxonomy of aerobic actinomycetes: phospholipid composition. Biochemical Systematics and Ecology 5, 249-260.

Lechevalier, M. P., Stern, A. E. \& Lechevalier, H. A. (1981). Phospholipids in the taxonomy of actinomycetes. Zentralblatt für Bakteriologie, Mikrobiologie und Hygiene (Abteilung I, Supplement 11), 111-116.

Locci, R. \& Petrolini, B. B. (1970). Morphology and development of Streptoverticillium species as examined by scanning electron microscopy. Giornale di microbiologia 18, 69-76.

Locci, R., Baldacci, E. \& Petrolini, B. B. (1969). The genus Streptoverticillium. A taxonomic study. Giornale di microbiologia 17, 1-60.

Locci, R., Rogers, J., SARd, P. \& Schofield, G. M. (1981). A preliminary numerical study on named species of the genus Streptoverticillium. Annali di Microbiologia 31, 115-121.

Minnikin, D. E. \& O'Donnelt, A. G. (1984). Actinomycete envelope lipid and peptidoglycan composition. In The Biology of the Actinomycetes, pp. 335-388. Edited by M. Goodfellow, M. Mordarski, \& S. T. Williams. London: Academic Press.

Prauser, H. (1976). Host-phage relationships in nocardioform organisms. In The Biology of the Nocardiae, pp. 266-284. Edited by M. Goodfellow, G. H. Brownell \& J. A. Serrano. London: Academic Press.

Pridham, T. G.\& Tresner, H. D. (1974). Streptomyces Waksman and Henrici 1943. In Bergey's Manual of Determinative Bacteriology, 8th edn, pp. 747-829. Edited by R. E. Buchanan \& N. E. Gibbons. Baltimore: Williams \& Wilkins.

Shirling, E. B. \& Gotlieb, D. (1966). Methods for characterisation of Streptomyces species. International Journal of Systematic Bacteriology 16, 313-340.

SiERra, G. (1957). A simple method for the detection of lipolytic activity of microorganisms and some observations on the influence of the contact between cells and fatty substrates. Antonie van Leeuwenhoek 23, $15-22$.

Skerman, V. B. D., McGowan, V. \& Sneath, P. H. A. (1980). Approved lists of bacterial names. International Journal of Systematic Bacteriology 30, 225-420.

SNeath, P. H. A. (1974). Test reproducibility in relation to identification. International Journal of Systematic Bacteriology 24, 508-523.
SNEATH, P. H. A. (1979a). Basic program for identification of an unknown with presence-absence data against an identification matrix of percent positive characters. Computers and Geosciences 5, 195-213.

SNEATH, P. H. A. (1979 b). Basic program for character separation indices from an identification matrix of percent positive characters. Computers and Geosciences 5, 349-357.

SNEATH, P. H. A. (1980a). Basic program for the most diagnostic properties of groups from an identification matrix of percent positive characters. Computers and Geosciences 6, 21-26.

SNEATH, P. H. A. (1980 $b$ ). Basic program for determining the best identification scores possible for the most typical example when compared with an identification matrix of percent positive characters. Computers and Geosciences 6, 27-34.

SNEATH, P. H. A. (1980c). Basic program for determining overlap between groups in an identification matrix of percent positive characters. Computers and Geosciences 6, 267-278.

SNeath, P. H. A. \& SoKal, R. R. (1973). Numerical Taxonomy. The Principles and Practice of Numerical Classification. San Francisco: W. H. Freeman.

Tresner, H. D. \& BaCKUS, E. J. (1963). System of color wheels for streptomycete taxonomy. Applied Microbiology 11, 335-338.

VickeRs, J. C., WILliams, S. T. \& Ross, G. W. (1984). A taxonomic approach to selective isolation of streptomycetes from soil. In Biological, Biochemical and Biomedical Aspects of Actinomycetes, pp. 553561. Edited by L. Ortiz-Ortiz, L. F. Bojalil \& V. Yakoleff. Orlando: Academic Press.

Wellington, E. M. H. \& Williams, S. T. (1981). Host ranges of phage isolated to Streptomyces and other genera. Zentralblatt für Bakteriologie, Mikrobiologie und Hygiene, (Abteilung I, Supplement 11), 93-98.

Willcox, W. R., Lapage, S. P., Bascomb, S. \& CURTIS, M. A. (1973). Identification of bacteria by computer: theory and programming. Journal of General Microbiology 77, 317-330.

W ILLIAMS, S. T. (1967). Sensitivity of streptomycetes to antibiotics as a taxonomic character. Journal of General Microbiology 46, 151-160.

Williams, S. T., Goodfellow, M., Alderson, G., Wellington, E. M.H., Sneath, P. H. A.\& SaCkin, M. J. (1983a). Numerical classification of Streptomyces and related genera. Journal of General Microbiology 129, 1743-1813.

Williams, S. T., Goodfellow, M., Wellington, E. M. H., Vickers, J. C., Alderson, G., SNeath, P. H. A., SACKin, M. J. \& Mortimer, A. M. (1983b). A probability matrix for identification of some streptomycetes. Journal of General Microbiology 129 , $1815 \cdots 1830$. 